\title{
A Preliminary Study on Zooplankton Fauna of Kizılca Pond (Konya-Seydişehir/Turkey)
}

\author{
Meral APAYDIN YAĞCI* İsmail ERBATUR Abdullah DEMİR \\ ${ }^{1}$ Fisheries Research Insititute, Eğirdir, Isparta, Turkey
}

Abdulkadir YAĞCI

Kabul/Accepted: 13.04 .2021 Bir Ön Çalışma. Anadolu Çev. ve Hay. Dergisi, 6(3), 341-344.

*(iD): https://orcid.org/0000-0002-2108-1853 (iD) : https://orcid.org/0000-0003-1613-6650 (iD) : https://orcid.org/0000-0001-8881-2932 (iD) : https://orcid.org/0000-0002-7897-1734

\section{*Corresponding author's:} Meral APAYDIN YAĞCI Fisheries Research Insititute, Eğirdir, Isparta, Turkey

凶: meralyagci@ gmail.com

\begin{abstract}
Kizılca Pond has the most intensive population of Giant Spring Minnow fish (Pseudophoxinus anatolicus). To draw attention to the distribution area of the Anatolian endemic species, this pond was chosen as the study area and this preliminary study was carried out on onetime zooplankton species diversity in July 2018. Zooplankton samples were taken from the pelagic part of the lake at $8 \mathrm{~m}$ depth (sampling just once from this depth). Also, samples were collected with Hydro-Bios model plankton net with $55 \mu \mathrm{m}$ mesh size. Physicochemical parameters of the lake $(\mathrm{pH}$, conductivity, water temperature, dissolved oxygen concentration, saturation of dissolved oxygen) were measured. The zooplankton fauna of the pond consist of Rotifera (87\%) and Cladocera groups (13\%). The dominant species were recorded as Asplanchna priodonta, Keratella cochlearis and Testudinella patina.
\end{abstract}

Keywords: Cladocera, freshwater, kızılca pond, physicochemical parameters, rotifera.
*Sorumlu yazar: Meral APAYDIN YAĞCI

Su Ürünleri Araştırma Enstitüsü Müdürlüğü,

Eğirdir, Isparta, Türkiye

凶: meralyagci@gmail.com
Öz: Kızılca Göleti en yoğun yağ balıkları (Pseudophoxinus anatolicus) popülasyonuna sahiptir. Anadolu endemik türünün yayılış alanına dikkat çekmek amacıyla çalışma alanı olarak bu gölet seçilmiş ve bu ön çalışma Temmuz 2018'de tek seferlik zooplankton tür çeşitliliği üzerinde gerçekleştirilmiştir. Zooplankton örnekleri $8 \mathrm{~m}$ derinlikte (bu derinlikten sadece bir kez örnekleme) gölün pelajik bölgesinden alınmıştır. Ayrıca, örnekler $55 \mu \mathrm{m}$ göz açıklığındaki Hydro-Bios model plankton kepçesi ile toplanmıştır. Gölün fizikokimyasal parametreleri $(\mathrm{pH}$, iletkenlik, su sıcaklığ1, çözünmüş oksijen konsantrasyonu, çözünmüş oksijen doygunluğu) ölçülmüştür. Göletin zooplankton faunası Rotifera (\%87) ve Cladocera gruplarından (\%13) oluşmuştur. Baskın türler Asplanchna priodonta, Keratella cochlearis ve Testudinella patina olarak kaydedilmiştir.

Anahtar kelimeler: Cladocera, fizikokimyasal parametreler, kızılca göleti, rotifera, tatlısu.

\section{INTRODUCTION}

In the lake ecosystem, zooplanktonic organisms transfer carbon and energy from the primary producers to the living beings at higher trophic levels, such as invertebrates, fish and waterfowl, and limit the presence of phytoplankton. Rotifera is a large group of zooplankton
(Apaydın Yağcı et al., 2015; Bulut \& Saler, 2018; Tasevska et al., 2017). Some zooplankton types, especially Rotifers, are used as indicators to determine the water quality of freshwater ecosystems (Jeppesen et al., 2011; Saksena, 1987). 
Turkey inland zooplankton checklist consists of a total of 661 taxa including 417 Rotifera, 103 Cladocera and 141 Copepoda (Ustaoğlu, 2015). In Turkey, there are studies on zooplankton fauna in some ponds such as Tadım, Beytepe, Topboğazı, TMİ 12, Alıç, ŞekerReşadiye-Zincidere, Orduzu, Kaldırım and Halikan, Keçiborlu and Kapıaçmaz (Apaydın Yağcı et al., 2017; Bozkurt \& Dural, 2005; Bulut, 2018; Bulut \& Saler, 2016; Güher \& Erdoğan, 2008; Gürel \& Saler, 2015; Kaya et al., 2009; Korkmaz \& Korkmaz, 2002; Saler \& Arslan, 2007; Saler \& Şen, 2002). The purpose of this study is to conduct zooplankton study for the first time in Kizılca pond and to contribute to the biodiversity of zooplankton in Turkey.

\section{MATERIAL AND METHOD}

The body height of the Kızılca pond, which was built for irrigation purposes in Seydişehir District Kızılca Village by the Konya special provincial directorate of administration in 2010, is $22 \mathrm{~m}$, its body length is $294 \mathrm{~m}$, the maximum water elevation is $15 \mathrm{~m}$ and its area is 14.55 ha. The average depth is 6-8 m. Length of the pond: $943 \mathrm{~m}$, width of the pond: $186 \mathrm{~m}$ (KOP, 2011). Classified as endangered in The IUCN Red List of Threatened Species, Giant Spring Minnow or Anatolian Minnow (Pseudophoxinus anatolicus Hanko, 1925) has a range that includes the Beyşehir-Seydişehir / Konya region (Figure 1).

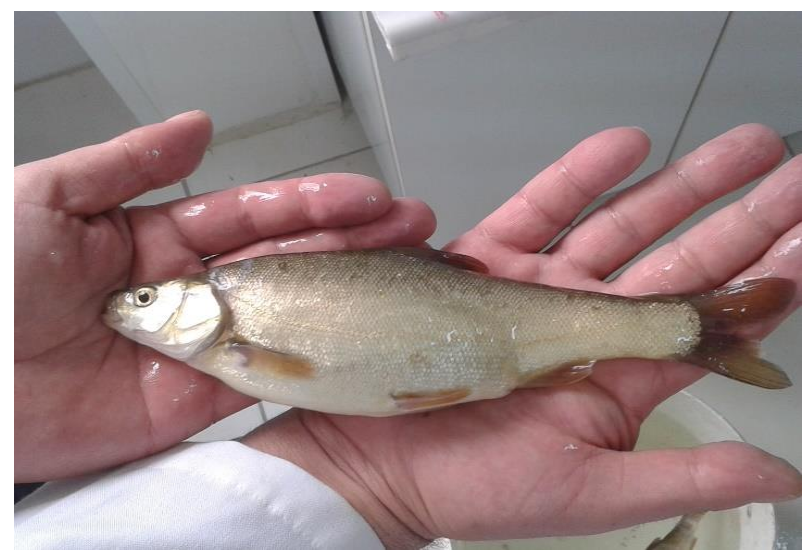

Figure 1. Anatolian endemic Giant Spring Minnow fish (Pseudophoxinus anatolicus).

Zooplankton samples were taken from the pelagic part of the lake at $8 \mathrm{~m}$ depth (from this depth, one time) in July 2018 (Figure 2, 3). The samples were collected horizontally with Hydro-Bios model plankton net with 55 $\mu \mathrm{m}$ mesh opening and fixed with $4 \%$ formaldehyde solution. Then they have been checked and diagnosed in invert, stereo and research microscope using the related resources for zooplankton species (Koste, 1978; Negrea, 1983; Nogrady \& Segers, 2002; Segers, 1995; Smirnov, 1996; Ustaoğlu, 2004; Ustaoğlu et al., 2012; Ustaoğlu, 2015).

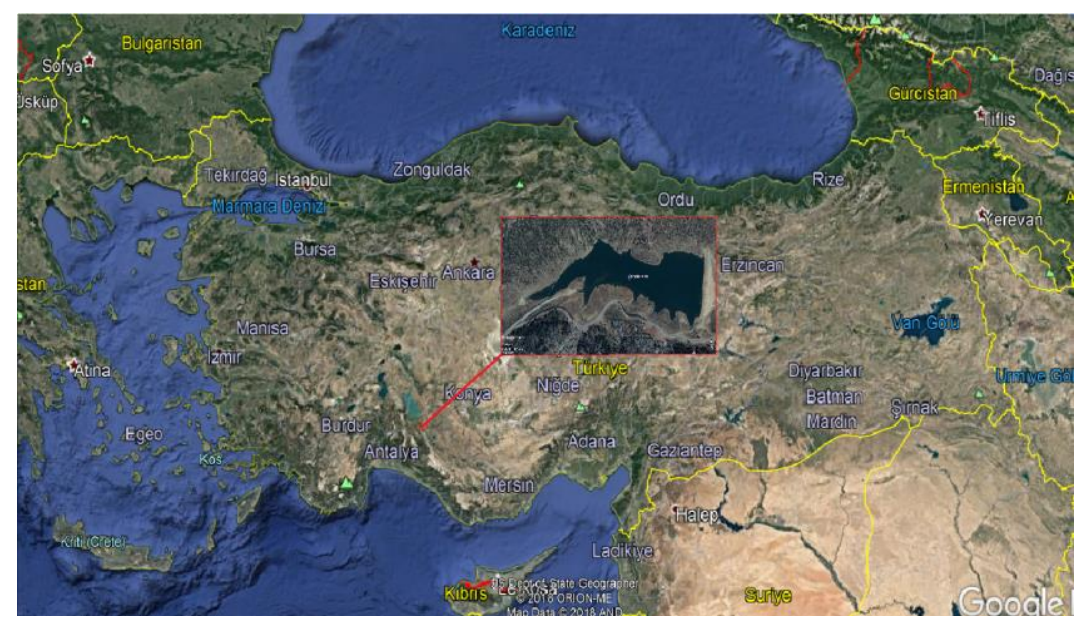

Figure 2. Study area (Coordinate; $\left.37^{\circ} 32^{\prime} 44.05^{\prime \prime} \mathrm{N}, 31^{\circ} 42^{\prime} 34.84^{\prime \prime E}\right)$.

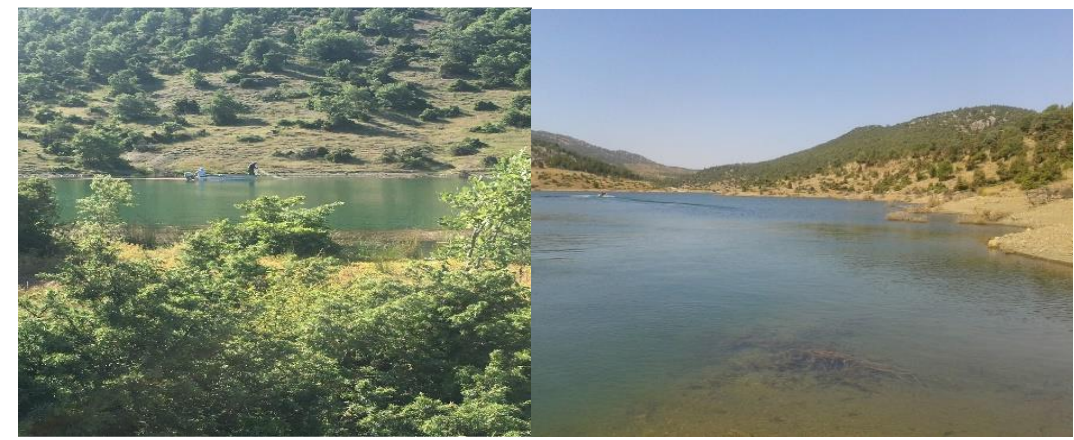

Figure 3. Kızılca pond. 


\section{RESULTS}

At the end of the study, a total of 15 species, 13 from Rotifera and 2 from Cladocera, were identified. The distribution of the identified species is provided in Table 1. In the pond, $\mathrm{pH} 8.58$, conductivity $194 \mu \mathrm{mhos} / \mathrm{cm}$, water temperature $27.1{ }^{\circ} \mathrm{C}$, dissolved oxygen $7.9 \mathrm{mg} / \mathrm{L}$, and dissolved oxygen saturation was measured as $94 \%$. Zooplankton species show a distribution in two groups. Rotifera (87\%), Cladocera (13\%) (Figure 4).

Table 1. Kizılca pond zooplankton species.

\begin{tabular}{|c|c|}
\hline Species & Density \\
\hline \multicolumn{2}{|l|}{ Rotifera } \\
\hline Ascomorpha sp. & $\boldsymbol{\Delta}$ \\
\hline Asplanchna priodonta & $\boldsymbol{\Delta} \boldsymbol{\Delta} \mathbf{\Delta}$ \\
\hline Colurella sp. & $\Delta$ \\
\hline Keratella cochlearis & $\Delta \boldsymbol{\Delta}$ \\
\hline Keratella testudo & $\boldsymbol{\Delta}$ \\
\hline Lecane bulla & $\boldsymbol{\Delta}$ \\
\hline Lecane luna & $\boldsymbol{\Delta}$ \\
\hline Lecane ludwigi & $\boldsymbol{\Delta}$ \\
\hline Lecane lunaris & $\boldsymbol{\Delta}$ \\
\hline Polyarthra dolichoptera & $\boldsymbol{\Delta}$ \\
\hline Synchaeta pectinata & $\boldsymbol{\Delta}$ \\
\hline Testudinella patina & $\boldsymbol{\Delta} \boldsymbol{\Delta}$ \\
\hline Trichocerca similis & $\boldsymbol{\Delta}$ \\
\hline \multicolumn{2}{|l|}{ Cladocera } \\
\hline Bosmina longirostris & $\boldsymbol{\Delta}$ \\
\hline Daphnia cucullata & $\boldsymbol{\Delta}$ \\
\hline
\end{tabular}

The maximum number of species was identified in the Rotifera group (13 species). Dominant species were identified as A. priodonta, K. cochlearis and T. patina from Rotifera.

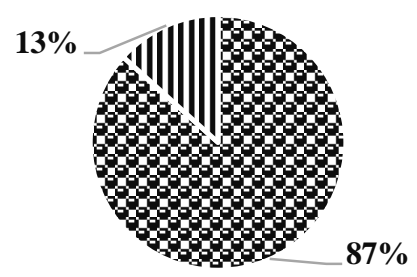

\section{- ROTIFERA I CLADOCERA}

Figure 4. Distribution of zooplankton groups in Kızılca Pond.

\section{DISCUSSION AND CONCLUSION}

Biotic and abiotic factors have been reported to be effective in the density and distribution of zooplankton species. Of these factors, especially temperature, oxygen, nutrients, competition and predation affect zooplankton (Tasevska et al., 2017). Zooplankton is important in the change of ecological and trophic conditions of lakes related to nutrient elements and changes caused by climate in lakes (Jeppesen et al., 2011). Among the Zooplankton species, especially the Rotifera group organisms are used as indicators of lakes (Gannon \& Stemberger, 1978). In the study on zooplankton fauna (Gürel \& Saler, 2015) in the Orduzu (Malatya) pond, a total of 47 zooplankton species were reported, 7 of them (A. priodonta, K. cochlearis, $L$. luna, L. lunaris, P. dolichoptera, S. pectinata, T. similis and $B$. longirostris) are compatible with the zooplankton fauna of Kiz1lca pond. Additionally, a total of 24 species were identified in the seasonal change study of zooplankton in the Kapıaçmaz pond (Kovancılar, Elazı ̆), among which A. priodonta, K. cochlearis, L. luna, $P$. dolichoptera, S. pectinata and B. longirostris species were also identified in Kizilca pond (Bulut, 2018). In the study conducted on the Rotifera species of zooplanktonic organisms in some of the wetlands of Kayseri, ReşadiyeŞeker and Zincidere ponds, K. cochlearis, L.luna, L. lunaris, $P$. dolichoptera and S. pectinata species were also detected in Kizılca pond (Kaya et al., 2009). Polyarthra sp, Keratella sp, Lecane sp, Bosmina sp and Daphnia sp species detected at the genus level in Beytepe (Ankara) pond are also similar to zooplanktonic organisms detected in Kizilca pond (Korkmaz \& Korkmaz, 2002). In the study conducted on the Kaldirım and Halikan ponds, a total of 52 zooplankton species were identified in the Kaldırım pond, and 45 zooplankton species were identified in the Halikan pond, and 11 zooplankton species identified in the Kaldırım and Halikan ponds (A. priodonta, K. cochlearis, L.luna, L. bulla, L. lunaris, P. dolichoptera, S. pectinata, T. similis, B. longirostris and D. cucullata) have also been identified in the Kizilca pond (Bulut \& Saler, 2016). In the research conducted in the Üçpınar (Uşak) pond, a total of 30 zoplankton species were identified, and P.dolichoptera and $T$. similis species were also found in the Krzilca pond (Ertosun et al., 2010). The zooplankton study conducted in Kizılca pond is the first one and all of the determined zooplankton species contributed to the region and zooplankton species diversity. It has become important that the biodiversity of the Kizılca pond ecosystem be studied thoroughly in the future in terms of ensuring the sustainability of the population of Anatolian endemic Giant Spring Minnow fish, which has a dense population in the region.

\section{ACKNOWLEDGEMENTS}

This study was presented as an oral presentation at the 4th International Anatolian Agriculture, Food, Environment and Biology Congress held in Afyonkarahisar between 20-22 April 2019.

\section{REFERENCES}

Apaydın Yağcı, M., Yeğen, V., Yağcı, A. \& Uysal, R. (2017). A preliminary study on zooplankton 
species in different aquatic habitats of Anatolia (Turkey). Journal of Limnology and Freshwater Fisheries Research, 3(1), 45-50. DOI: 10.17216/LimnoFish277465.

Apaydın Yağcı, M., Yılmaz, S., Yazıcıoğlu, O. \& Polat, N. (2015). The zoplankton composition of Lake Ladik (Samsun, Turkey). Turkish Journal of Zoology, 39, 652-659.

Bozkurt, A. \& Dural, M. (2005). Topboğazı Göleti (Hatay) zooplanktonunun vertikal göçü. Türk Sucul Yaşam Dergisi, 3(4), 104-109.

Bulut, H. \& Saler, S. (2016). Assessment of zooplankton by the index analysis in Kaldırım and Halikan Ponds, Malatya/Turkey. Biological Diversity and Conservation, 9(3), 70-77.

Bulut, H. \& Saler, S. (2018). Seasonal variations in zooplankton community of an aquatic ecosystem at Susurluk Basin (Balıkesir-Turkey). Fresenius Environmental Bulletin, 27(4), 2530-2535.

Bulut, H. (2018). Seasonal variation of Kapıaçmaz pond zooplankton in Elazığg, Turkey. Turkish Journal of Agriculture-Food Science and Technology, 6(11), 1617-1621.

Ertosun, B., Altındağ, A. \& Ahiska, S. (2010). The determination trophic status of Ucpinar Dam Lake (Usak, Turkey). Journal of Animal and Veterinary Advances, 9(3), 491-495.

Gannon, J.E. \& Stemberger, R.S. (1978). Zooplankton (especially crustacean and rotifers) as indicators of water quality. Transactions of the American Microscopical Society, 97, 16-35.

Güher, H. \& Erdoğan, S. (2008). Alıç Göleti Perifitik zooplankton (cladocera, copepoda, rotifera) türleri üzerine bir araştırma. Journal of FisheriesSciences.com, 2(3), 516-523. DOI: 10.3153/jfascom.mug.200749

Gürel, Ö. \& Saler, S. (2015). Zooplankton of Orduzu Lake (Malatya). Firat Univ. Journal of Science, 27(1), 21-28.

Jeppesen, E., Nõges, P., Davidson, T.A., Haberman, J., Nõges, T., Blank, K., Lauridsen, T.L., Søndergaard, M., Sayer, C., Laugaste, R., Johansson, L.S., Bjerring, R. \& Amsinck, S.L. (2011). Zooplankton as indicators in lakes a plea for including zooplankton in the ecological quality assessment of lakes according to the European Water Framework Directive (WFD). Hydrobiologia, 676, 270-297.

Kaya, M., Duman, F. \& Altındağ, A. (2009). Recorded rotifer species from some aquatic habitats (Şeker Pond, Reşadiye Pond, Zincidere Pond, Mimarsinan Park Pool, Hisarcık Stream, Kumalı Park Pool) in Kayseri. SDÜ Fen Dergisi (EDergi), 4(1), 54-58.

KOP. (2011). http://kop.gov.tr/upload/dokumanlar/61.pdf. KOP Küçük ölçekli Sulama İşleri Programı. Konya Ovası Projesi Bölge Kalkınma İdaresi Başkanlığı. 40s.

Korkmaz, S. \& Korkmaz, Ş. (2002). A Research on seasonal composition of zooplankton in Beytepe Reservoir. Tarım Bilimleri Dergisi, 8(4), 338-343.
Koste, W. (1978). Rotatoria, die rädertiere mitteleuropas ein bestimmungswerk, begründet von max voigt überordnung Monogononta, I Textband. Gebrüder Borntraeger, Berlin, Stuttgart, 672P and II Textband. 234p.

Negrea, S. (1983). Fauna republici socialiste Romania. Crustacea, Cladocera. 4, 12, Acedemia Rep. Soc. Romania, Bucuresti. 367p.

Nogrady, T. \& Segers, H. (2002). Asplanchnidae, Gastropodidae, Lindiidae, Microcodidae, Synchaetidae, Trochosphaeridae and Filinia, Vol.6, Guides to the Identification of the Microinvertebrates of the Continental Waters of the World. Coordinating editor: HJF. Dumont. Kingston Ont. Canada Gent Univ.,Belgium Backhuys Pub.Leiden, The Netherlands. 264p.

Saksena, D.N. (1987). Rotifers as indicators of water quality. Acta Hydrochimica et Hydrobiologica, 15, 481-485.

Saler, S. \& Arslan, S. (2007). TMI 12 Göleti (Elazığ) copepoda ve cladocera (crustacea) faunas1. Ege Üniversitesi Su Ürünleri Dergisi, 24(1-2), 191193.

Saler, S. \& Şen, D. (2002). Tadım Göleti (Elazı̆̆-Türkiye) rotiferlerinin (Rotatoria, Aschelminthes) mevsimsel değişimleri. F.̈̈. Fen ve Mühendislik Bilimleri Dergisi, 14 (1), 235-240.

Segers, H. (1995). The Lecanidae (Monogononta), Vol. 2, Guides to the Identification of the Microinvertebrates of the Continental Waters of the World, Coordinating editor: HJF. Dumont. Gent Univ., Belgium, SPB Academic Publishing., The Netherlands. 226p.

Smirnov, N.N. (1996). Guides to the identification of the microinvertabrates of the continental waters of the word. Cladocera: The Chydorinae and Sayciinae (Chydoridae) of the World. No. 11, Coordinating editor: HJF. Dumont. Gent Univ., Belgium, SPB Academic., The Netherlands. 197p.

Tasevska, O., Špoljar, M., Gušeska, D., Kostoski, G., Patcheva, S. \& Veljanoska Sarafiloska, E. (2017). Zooplankton in ancient and oligotrophic Lake Ohrid (Europe) in association with environmental variables. Croatian Journal of Fisheries, 75, 95-103.

Ustaoğlu, M.R. (2004). A Checklist for zooplankton of Turkish inland waters. Ege Journal of Fisheries and Aquatic Sciences, 21, 191-199.

Ustaoğlu, M.R. (2015). An updated zooplankton biodiversity of Turkish inland waters. Journal of Limnology and Freshwater Fisheries Research, 1(3), 151-159. DOI: 10.17216/LimnoFish5000151941

Ustaoğlu, M.R., Altındă̆, A., Kaya, M., Akbulut, N., Bozkurt, A., Özdemir Mis, D., Atasagun, S., Erdoğan, S., Bekleyen, A., Saler, S. \& Okgerman, H. (2012). A checklist of Turkish rotifers. Turkish Journal of Zoology, 36(5), 607622. 